\title{
PEMBERDAYAAN UKM MAKANAN OLAHAN CARICA DI WONOSOBO, JAWA TENGAH
}

Eny Endah Pujiastuti', Humam Santosa Utomo², Suratna3

1,2,3Universitas Pembangunan Nasional Veteran Yogyakarta

1E-mail address eny.endahp@upnyk.ac.id; 2E-mail address

humam.santosautomo@upnyk.ac.id; 3E-mail address suratna@upnyk.ac.id

\begin{abstract}
The community service program is carried out at one of the SMEs in Wonosobo, Central Java, which produces and markets processed carica food products. The problems faced by SMEs are problems in the aspects of marketing, financial management and production. The purpose of community service is to improve the ability of SMEs to market products, manage company finances, increase the efficiency of the production process, and increase production capacity. The approach used in this community service is training and business assistance. The results felt by SMEs are the wider marketing of carica processed food products, structuring the company's financial system, efficiency in the production process, and increased production capacity.
\end{abstract}

Keywords: Small and Medium Enterprises, Empowerment of SMEs

\begin{abstract}
Abstrak
Program pengabdian masyarakat dilakukan pada salah satu UKM di Wonosobo, Jawa Tengah yang memproduksi dan memasarkan prduk makanan olahan carica. Permasalahan yang dihadapi UKM adalah permasalahan pada aspek pemasaran, manajemen keuangan, dan produksi. Tujuan pengabdian masyarakat ditujukan untuk meningkatkan kemampuan UKM dalam memasarkan produk, mengelola keuangan perusahaan, meningkatkan efisiensi proses produksi, dan meningkatkan kapasitas produksi. Pendekatan yang digunakan dalam pengabdian masyarakat ini adan pelatihan dan pendampingan bisnis. Hasil yang dirasakan oleh UKM adalah semakin luasnya pemasaran produk makanan olahan carica, tertatanya sistem keuangan perusahaan, efisiensi dalam proses produksi, serta meningkatnya kapasitas produksi.
\end{abstract}

\section{Kata Kunci: Usaha Kecil Menengah, Pemberdayaan UKM}

\section{PENDAHULUAN}

Desa Sembungan, Kejajar, Wonosobo, Jawa Tengah memiliki ketinggian tanah +2300 permukaan laut menjadikan desa tertinggi di Jawa
Tengah. Suhu udara rata-rata $15^{\circ} \mathrm{C}$ sehingga wilayah ini tergolong dingin. Desa Sembungan merupakan satu kawasan yang letak topografinya dikelilingi oleh pegunungan antara lain 
gunung Paku Waja, Sikunir, dan Bisma. Salah satu potensi desa ini adalah kondisi alamnya yang dingin menjadikan pohon carica dapat tumbuh subur.

UD. Pondok Mulya merupakan salah satu UKM di Desa Sembungan, Kejajar, Wonosobo, Jawa Tengah yang memproduksi berbagai macam jenis makanan olahan dari bahan dasar buah carica. Buah carica masuk dalam keluarga pepaya yang hanya bisa tumbuh di tempat tinggi, memerlukan temperatur yang cukup dingin, dan banyak hujan. Kondisi tersebut sangat cocok dengan iklim dataran tinggi Dieng di Wonosobo. Nama latin buah carica ini adalah Carica Pubescens atau Carica Candamarcensis, atau kadang dikenal sebagai Mountain Papaya, atau penduduk setempat mengenal sebagai gandul dieng.

Bahan baku carica mudah dijumpai di wonosobo. Pohon carica dapat tumbuh subur di daerah ini sehingga UD Pondok Mulya tidak mengalami hambatan yang berarti pada bahan bakunya. Kualitas bahan baku juga dapat dipertahankan karena suplainya yang relatif banyak. UD. Pondok Mulya merupakan induk dari plasma petani yang berada di sekitar perusahaanya. Perusahaan menampung buah carica dari petani, disamping juga menanam sendiri untuk diproduksi menjadi berbagai jenis makanan. UD. Pondok Mulya membeli carica dari petani dengan harga yang wajar sehingga petani tidak rugi menanam carica.

Pada awalnya buah carica hanya dijual begitu saja, tanpa mengalami proses produksi, namun UD Pondok Mulya mencoba memberikan nilai tambah buah carica dengan memprosesnya menjadi berbagai macam variasi makanan yang lebih bernilai ekonomis. Peralatan produksinya masih relatif sederhana sehingga kapasitas produksinya belum optimal. Kontrol terhadap kualitas masih dilakukan secara manual karena keterbatasan peralatan modern sehingga diharapkan dapat dikembangkan teknologi yang mendukung. Nilai investasinya belum dapat diukur secara pasti mengingat usaha ini merupakan usaha kecil yang memiliki keterbatasan dalam penghitungan keuangan. Layout produksinya menggunakan alur proses mulai dari penyiapan bahan baku sampai dengan pengepakan. Berdasarkan observasi di lapangan, lay out masih harus diperbaiki agar lebih efisien.

Jenis produk yang dihasilkan adalah sirup, selai, dan kripik. Setiap bulan perusahaan dapat menjual lebih dari 1.500 botol sirup carica. Sebenarnya 
pasar sangat tinggi namun karena proses produksinya sebagian besar masih dilakukan secara manual maka sulit untuk memenuhi permintaan pasar. Perencanaan produksinya belum dilakukan dengan sistem just in time atau Economic Order Quantity sehingga tingkat efisiensinya masih relatif rendah.

Pembukuan keuangan sudah dilakukan oleh perusahaan namun belum mengacu pada akuntansi yang baku artinya masih dilakukan secara sederhana sehingga mengalami kesulitan untuk menghitung aset, rugi laba, dan sebagainya. Pembukuan juga masih manual sehingga penyiapan data keuangan masih menemui kendala. Manajemen keuangan dan pembukuan dilakukan sendiri oleh pemilik perusahaan sehingga tidak dilakukan monitoring dan auditing. Pencatatan inventory juga belum dilakukan secara profesional sehingga kesulitan untuk melakukan pengawasan stok barang.

Daerah pemasaran UD. Pondok Mulya masih terbatas di kota Wonosobo dan Semarang. Keterbatasan kemampuan dalam mengembangkan jaringan pemasaran menyebabkan terbatasnya daerah pemasaran ini. Teknik pemasarannya mengandalkan distribusi melalui toko-toko makanan khas atau kerja sama dengan pengepul sehingga belum merambah ke supermarket atau lainnya. Segmen pasar yang dibidik belum jelas sehingga diferensiasi produknya belum nampak. Promosi tidak pernah dilakukan oleh perusahaan karena pertimbangan biaya.

Eksistensi UD. Pondok Mulya sangat diharapkan oleh masyarakat sekitar, terutama petani dan buruh untuk dapat bekerja di perusahaan ini. Keterbatasan lapangan pekerjaan dan nasib para petani yang sering dipermainkan oleh pasar menyebabkan kehidupan masyarakat yang sebagian besar petani sulit untuk maju. Buah carica adalah salah satu komoditas yang dapat diandalkan oleh masyarakat di wilayah ini sehingga pengembangan produk carica sangat diharapkan. Oleh karena itu sangat penting dilakukan upaya penguatan UD Pondok Mulya yang merupakan induk plasma petani untuk meningkatkan kesejahteraan masyarakat.

Berdasarkan hasil observasi awal dan wawancara mendalam dengan pemilik perusahaan, dapat diidentifikasi permasalahan-permasalahan yang dihadapi oleh mitra. Permasalahan ditemukan dari beberapa hal yang dirasakan menghambat pertumbuhan perusahaan atau bahkan mengancam kelangsungan usaha. Permasalahan 
pertama adalah keterbatasan akses pasar yang dapat didentifikasi dari terbatasnya pasar yang dilayani dan pasar yang selama ini dilayani tidak berkembang. Sementara itu, masih terbuka luas kesempatan untuk mengembangkan pasar. Permasalahan kedua adalah terbatasnya kemampuan pembukuan sehingga UD. Pondok Mulya merasakan kesulitan dalam menentukan aset perusahaan, menentukan rugi/laba, dan mengontrol keuangan. Permasalahan ketiga adalah pada aspek efsiensi produksi. UD. Pondok Mulya belum memiliki teknologi tepat guna yang mampu diaplikasikan dalam proses produksi.

Permasalahan yang dialami UD. Pondok Mulya relevan dengan pendapat Winarni (2006), yang mencirikan usaha kecil memeiliki bebeapa permasalahan antara lain: (1) Biasanya di dari bisnis individu dan belum dalam bentuk perusahaan perusahaan, (2) Aspek hukum dari bisnis lemah, (3) Struktur organisasi sederhana dan pembagian tugas tidak masuk standar, (4) Sebagian besar bisnis tidak memiliki laporan keuangan dan tidak memisahkan pribadi kekayaan dan kekayaan perusahaan, (5) Kualitas manajemen rendah dan jarang memiliki bisnis rencana, (6) Sumber modal utama adalah modal pribadi, (7)
Sumber daya manusia terbatas, (7) Pemilik memiliki ikatan pribadi yang kuat dengan perusahaan, sehingga semua tugas perusahaan juga menjadi tugas pemilik.

\section{METODE DAN PELAKSANAAN}

Pemberdayaan UKM pada UD. Pondok Mulya diperlukan dalam rangka meningkatkan kemampuan dalam menjalankan usahanya. Pemberdayaan dimaknai sebagai aspek mendasar dan penting untuk keberhasilan pencapaian, produktivitas, dan pertumbuhan bisnis apapun (Hunjra et al., 2011). Empowerment adalah memaksimalkan pemanfaatan ketrampilan dan keahlian (Cacciope, 1998). Tujuan pemberdayaan dimaksudkan untuk membantu UKM dalam meningkatkan potensi agar memiliki peluang hidup dan berkembang dalam rangka menghadapi persaingan yang sehat. Dengan pemberdayaan diharapkan terjadi optimalisasi kekuatan yang ada agar mampu memanfaatkan peluang serta mengatasi berbagai kelemahan dan tantangan yang ada (Sukidjo, 2004).

Pendekatan yang dilakukan pada program pemberdayaan UD. Pondok Mulya adalah pendampingan bisnis. Metode ini dirasakan paling tepat untuk mengatasi permasalahan yang dihadapi oleh perusahaan. Melalui pendampingan 
bisnis maka aspek-aspek strategis dan teknis dapat dilakukan. Pendampingan juga diharapkan mampu memastikan program-program perbaikan dilaksanakan secara konsisten. Dosen dibantu oleh mahasiswa membantu mitra untuk keluar dari permasalahanpermasalahan utama.

Solusi terhadap permasalahan yang dihadapi oleh mitra juga telah dibicarakan dan disepakati bersama. Pengabdi bersama-sama UKM mitra menyepakati beberapa solusi untuk memecahkan masalah sesuai kemampuan UKM dengan pendampingan pengabdi. Solusi yang dilakukan sebagaimana disajikan pada Tabel 1.

Tabel 1. Permasalahan Mitra dan Solusi

\begin{tabular}{|c|c|c|}
\hline No. & Permasalahan & Solusi \\
\hline 1. & $\begin{array}{c}\text { Keterbatasan } \\
\text { akses pasar }\end{array}$ & 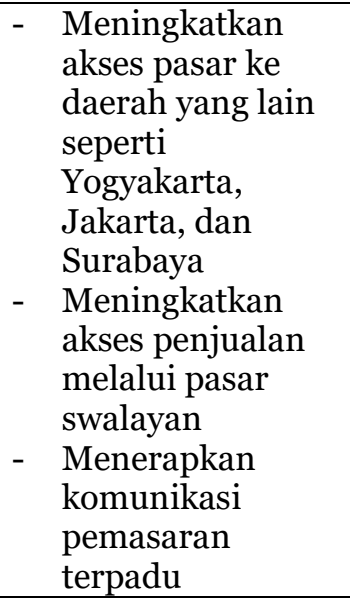 \\
\hline 2. & $\begin{array}{l}\text { Keterbatasan } \\
\text { kemampuan } \\
\text { pembukuan }\end{array}$ & $\begin{array}{ll}\text { - } & \text { Menghitung aset } \\
\text { perusahaan } \\
\text { - } & \text { Melakukan } \\
\text { pembukuan yang } \\
\text { lebih tertib } \\
\text { - } & \text { Menerapkan } \\
\text { mekanisme } \\
\text { kontrol baik }\end{array}$ \\
\hline 3. & Keterbatasan & - $\quad$ Merancang lay out \\
\hline
\end{tabular}

\begin{tabular}{|l|l|l|}
\hline No. & Permasalahan & \multicolumn{1}{c|}{ Solusi } \\
\hline & Produksi & produksi \\
& & - Merancang \\
& & Economic Order \\
& & Quantity (EOQ) \\
\hline
\end{tabular}

Permasalahan utama UD. Pondok Mulya adalah keterbatasan akses pasar sehingga solusi utama yang ditawarkan adalah komunikasi pemasaran terpadu (Integrated

Marketing

Communication/IMC). IMC adalah proses pengembangan dan implementasi berbagai bentuk program komunikasi persuasif kepada pelanggan dan calon pelanggan secara berkelanjutan. Proses IMC berawal dari pelanggan atau calon pelanggan, kemudian berbalik pada perusahaan untuk menentukan dan mendefinisikan bentuk dan metode yang perlu dikembangkan bagi program komunikasi yang persuasif. Solusi yang yang lain adalah peningkatan kemampuan mengelola keuangan dan merancang proses produksi yang lebih efisien. Solusi ditindaklanjuti dengan aktivitas sehingga benar-benar setiap aktivitas mengarah pada penyeleaian masalah. Solusi dan aktivitas disajikan pada Tabel 2.

Tabel 2. Solusi dan Kegiatan

\begin{tabular}{|c|l|l|}
\hline No. & \multicolumn{1}{|c|}{ Solusi } & \multicolumn{1}{c|}{ Aktivitas } \\
\hline 1. & Menerapkan & Analisis \\
& komunikasi & segmentasi, \\
& pemasaran terpadu & targeting, \\
& (IMC) & positioning \\
& & - Menentukan \\
& & tujuan \\
& & komunikasi \\
\hline
\end{tabular}




\begin{tabular}{|c|c|c|}
\hline No. & Solusi & Aktivitas \\
\hline & & $\begin{array}{ll} & \text { pemasaran } \\
\text { secara spesifik } \\
\text { - } & \text { Menyusun } \\
& \text { strategi } \\
\text { promosi } \\
\text { - } \text { Menentukan } \\
\text { alat komunikasi } \\
\text { pemasaran } \\
\text { terpadu } \\
\text { - Implementasi } \\
\text { IMC }\end{array}$ \\
\hline 2. & $\begin{array}{l}\text { Meningkatkan } \\
\text { akses pasar ke } \\
\text { daerah yang lain } \\
\text { seperti Yogyakarta, } \\
\text { Jakarta, dan } \\
\text { Surabaya }\end{array}$ & $\begin{array}{ll}\text { - } & \text { Penjajagan } \\
\text { kerja sama } \\
\text { - } \text { Pemberian } \\
\text { sampel } \\
\text { - } \text { Kontrak kerja } \\
\text { sama } \\
\text { - Pengiriman } \\
\text { barang }\end{array}$ \\
\hline 3. & $\begin{array}{l}\text { Meningkatkan } \\
\text { akses penjualan } \\
\text { melalui pasar } \\
\text { swalayan }\end{array}$ & $\begin{array}{l}\text { - Penjajagan } \\
\text { kerja sama } \\
\text { - } \text { Pemberian } \\
\text { sampel } \\
\text { - } \text { Kontrak kerja } \\
\text { sama } \\
\text { - } \text { Pengiriman } \\
\text { barang }\end{array}$ \\
\hline 4. & $\begin{array}{l}\text { Menghitung aset } \\
\text { perusahaan }\end{array}$ & $\begin{array}{l}\text { - Menyiapkan } \\
\text { format } \\
\text { penghitungan } \\
\text { - Menyiapkan } \\
\text { standar harga } \\
\text { - Menghitung } \\
\text { aset } \\
\text { perusahaan } \\
\end{array}$ \\
\hline 5 . & $\begin{array}{l}\text { Melakukan } \\
\text { pembukuan yang } \\
\text { lebih tertib }\end{array}$ & $\begin{array}{l}\text { - } \text { Menyiapkan } \\
\text { materi } \\
\text { pelatihan } \\
\text { - } \text { Pemilahan aset } \\
\text { perusahaan } \\
\text { dengan pribadi } \\
\text { - } \text { Melatih } \\
\text { pembukuan } \\
\text { - Mendampingi } \\
\text { pembukuan } \\
\end{array}$ \\
\hline 6. & $\begin{array}{l}\text { Menerapkan } \\
\text { mekanisme kontrol } \\
\text { baik }\end{array}$ & $\begin{array}{l}\text { - Menyusun } \\
\text { format } \\
\text { mekanisme } \\
\text { kontrol } \\
\text { keuangan dan } \\
\text { logistik } \\
\text { - Implementasi } \\
\text { kontrol } \\
\end{array}$ \\
\hline 7. & $\begin{array}{l}\text { Merancang lay out } \\
\text { produksi }\end{array}$ & $\begin{array}{l}\text { - Evaluasi lay out } \\
\text { - Merancang lay } \\
\text { out } \\
\text { - Implementasi } \\
\text { lay out }\end{array}$ \\
\hline
\end{tabular}

\begin{tabular}{|c|l|l|}
\hline No. & \multicolumn{1}{|c|}{ Solusi } & \multicolumn{1}{|c|}{ Aktivitas } \\
\hline & & - Evaluasi \\
\hline 8. & Merancang & - Analisis Bahan \\
& $\begin{array}{l}\text { Economic Order } \\
\text { Quantity }\end{array}$ & Baku \\
& & Penerapan \\
Model EOQ
\end{tabular}

Permasalahan utama UD. Pondok Mulya adalah aspek pemasaran sehingga harus diarahkan untuk memenuhi permintaan konsumen dan meningkatkan akses pasar. Kegiatan diawali dengan menentukan target pasar. Target pasar UD. Pondok Mulya adalah distributor dan pengecer. Meskipun UD. Pondok Mulya juga menjual langsung ke konsumen akhir namun jumlahnya sangat terbatas. Dengan demikian maka perluasan jejaring pemasaran sangat dibutuhkan. Promosi juga lebih diarahkan untuk memberikan kemudahan bagi distributor atau pengecer dalam memperoleh informasi dan bekerja sama dengan UKM. Perluasan kerja sama telah dilakukan dengan toko oleh-oleh di Jakarta, Yogyakarta, dan Surabaya untuk menjual produk carica. Kegiatan ini dilanjutkan dengan pemberian sampel produk, kontrak kerja sama, dan pengiriman barang. Selain itu juga dilakukan kerja sama dengan swalayan yang berada di Yogyakarta dan Semarang.

Permasalahan manajemen keuangan diatasi dengan kegiatan pendampingan pembukuan sederhana 
sesuai dengan kemampuan UKM.

Pengabdi juga mendampingi dalam menghitung aset perusahaan, menghitung untung/rugi, maupun menentukan harga pokok. Kegiatan ini bertujuan untuk memudahkan UKM dalam merencanakan dan mengontrol keuangan sehingga tidak mengalami kerugian.

Permasalahan pada aspek produksi terkait dengan efisiensi proses produksi. Pengabdi bersama-sama dengan UKM menyusun layout produksi sehingga lebih efisien. Selain itu pengabdi juga memfasilitasi teknologi tepat guna berupa alat peniris carica, meskipun UKM sebelumnya sudah memiliki namun belum optimal hasilnya. Pengabdi juga mendampingi UKM dalam merancang perencanaan pembelian carica sehingga UKM tidak kekurangan stok atau kelebihan stok. Kelebihan stok bahan baku menyebabkan kualitas carica menurun sehingga berimplikasi pada kualitas produk.

\section{HASIL DAN PEMBAHASAN}

Hasil pengabdian masyarakat ini memberikan manfaat, baik bagi UKM, pengabdi, maupun institusi pengusul. Hasil yang dinikmati UKM adalah sebagai berikut:

1. Manfaat pada aspek pemasaran meliputi: a. UKM memiliki target pasar yang lebih jelas. Produk lebih diarahkan untuk semua konsumen, mulai dari anak-anak, remaja, maupun orang tua.

b. UKM memiliki beberapa kemasan (kecil, tanggung, dan besar) yang semula hanya memiliki satu kemasan saja dari bahan kaca. Selain itu, kemasan juga tidak hanya didesain bijian namun dikemas dalam 3 pack sehingga lebih menarik bagi konsumen sebagai oleh-oleh.

c. Desain kesaman lebih modern dari pada sebelumnya dengan merek dagang "sun rise".

d. Strategi distribusi produk lebih diarahkan dengan melakukan kerja sama penjualan dengan toko-toko oleh-oleh maupun swalayan modern. Sebelum pengabdian penjualan masih terbatas pada toko oleh-oleh saja.

e. Kerjasama penjualan meningkat sehingga wilayah pemasaran semakin luas yang meliputi kota Wonosobo, Semarang, Yogyakarta, dan Jakarta.

f. Harga tidak mengalami perubahan meskipun terjadi penambahan biaya kemasan 
karena tertutup oleh jumlah penjualan yang semakin banyak.

g. Promosi dilakukan dengan potongan harga dan dipublikasikan pada meia social.

2. Manfaat pada aspek keuangan meliputi:

a. Pembukuan lebih tertata meskipun masih sederhana disesuaikan dengan kemampuan UKM.

b. Pemisahan keuangan keluarga dengan keuangan perusahaan, meskipun tempat usaha masih jadi satu dengan tempat tinggal keluarga.

c. Kemudahan dalam mengetahui jumlah keuntungan atau kerugian berdasarkan laporan keuangan.

d. Logistik berupa bahan baku dan bahan pembantu lebih terkontrol sehingga meminimalisir kelebihan stok yang berakibat buah carica membusuk sebelum diolah atau kekurangan stok bahan baku.

3. Manfaat pada aspek produksi meliputi:

a. Proses produksi menjadi lebih efisien dengan layout produksi yang lebih baik sehingga material handling lebih sederhana. b. Kualitas produk lebih terstandarisasi melalui kontrol kualitas produk yang diterapkan.

c. Produksi lebih cepat melalui penambahan teknologi tepat guna sehingga meningkatkan kapasitas produksi.

Pengabdian masyarakat ini juga memberikan manfaat bagi pengabdi dan institusi yang meliputi:

1. Up dating iptek yang dibutuhkan oleh masyarakat sehingga pengabdi dapat menyerap informasi untuk kegiatan penelitian maupun pengabdian selanjutnya.

2. Peningkatan perhatian dunia pendidikan pada industri kecil meningkatkan citra perguruan tinggi.

\section{PENUTUP}

\section{Simpulan}

Pengabdian masyarakat memberikan manfaat bagi UKM mitra maupun bagi pengabdi. Pemberdayaan UKM melalui pelatihan dan pendampingan mampu meningkatkan kapasitas UKM dalam mengelola bisnis secara mandiri dan berkesinambungan. Manfaat utama yang dirasakan oleh UKM adalah meningkatnya luas pasar, manajemen keuangan yang lebih baik, dan manajemen produksi yang lebih 
meningkat. Pengabdian masyarakat yang menerapkan metode pandampingan dapat menjamin program pengabdian dijalankan oleh UKM mitra sehingga kesinambungannya akan terjaga. Program pengabdian masyarakat juga memberikan inspirasi bagi pengabdi untuk menemukan ide penelitian dan pengabdian selanjutnya yang benarbenar dibutuhkan oleh masyarakat.

\section{Saran}

Program pengabdian berikutnya dapat menggunakan metode ini jika memiliki karakteristik yang sama atau perlu penyesuaian ssuai karakteristik mitra, permasalahan yang dihadapi, dan potensi yang dimiliki.

\section{Ucapan Terima Kasih}

Ucapan terima kasih disampaikan kepada Direktorat Penelitian dan Pengabdian kepada Masyarakat dan LPPM UPN "Veteran" Yogyakarta yang telah memfasilitasi kegiatan pengabdian masyarakat.

\section{DAFTAR PUSTAKA}

Cacciope, R. (1998). Structured empowerment: an award winning programme at the Burswood Resort Hotel, Leadership and Organization Development Journal, Vol. 19 No.5, pp. 264-274 Hunjra, A. I., UlHaq, N., Akbar, S. W., \& Yousaf, M. (2011). Impact of employee empowerment on job satisfaction: An empirical analysis of Pakistani service industry. Interdisciplinary Journal of Contemporary Research in Business, 2(11), 680-685.

Sukidjo (2004).

STRATEGI

PEMBERDAYAAN USAHA KECIL DAN MENENGAH. Jurnal Ekonomi \& Pendidikan, Volume 2, Nomor 1, Agustus 2004

Winarni, Sri Endang (2006). Strategi Pengembangan Usaha Kecil Melalui Peningkatan Aksesibilitas Kredit Perbankan. Infokop. No. 29. Tahun.XXII. 